\title{
LA JOLLA NATURAL RADIOCARBON MEASUREMENTS VI
}

\author{
G. S. BIEN and L. J. PANDOLFI* \\ University of California, San Diego
}

\section{INTRODUCTION}

The following list of measurements contains selected results obtained by the La Jolla Radiocarbon Laboratory from November 1966 to July 1971. During the same period 382 measurements were made on treering-dated wood in studying secular variations of the atmospheric $\mathrm{C}^{14}$ level and of the absolute radiocarbon time scale [Suess, 1970a, 1970b]. Results of these measurements are not included here. Also not included are 124 measurements of $\mathrm{C}^{14}$ determinations in extraterrestrial material and results of other occasional investigations will be published elsewhere.

The work of the laboratory was interrupted for almost one year from mid-1969, due to the moving from Ritter Hall of the Scripps Institution of Oceanography to Mt. Soledad. New electronics are now in operation along with five proportional counters on a full time routine basis. Samples reported herein were counted in either a $1000 \mathrm{~cm}^{3}$ or a $400 \mathrm{~cm}^{3}$ stainless steel detector unless otherwise noted. Counting pressures of $850 \mathrm{~mm} \mathrm{Hg}$ and $760 \mathrm{~mm} \mathrm{Hg}$ were increased to $1000 \mathrm{~mm} \mathrm{Hg}$. Shielding in the interior of our $1.4 \mathrm{~m} \times 1.6 \mathrm{~m} \times 1.9 \mathrm{~m}$ 19-ton iron shield was increased with the addition of more lead bricks and new paraffin bricks containing $5 \%$ boron.

NBS oxalic acid was frequently used as a contemporary standard, except where noted. For background determinations $\mathrm{C}_{2 .} \mathrm{H}_{2}$ produced from commercially available calcium carbide was sometimes substituted for gas prepared from anthracite. Ages listed are conventional "Libby" ages, calculated with a half-life of 5568 years. For archaeologic wood samples, dates of the tree-ring-dated bristlecone-pine wood show the same $\mathrm{C}^{14}$ content as the samples mentioned in the text. These "calibrated" dates give, in good approximation, the true time of sample growth. Errors reported are $2 \sigma$ statistical counting error resulting from sample, backgound, and standard counting variations. In cases where a high accuracy was required, $\mathrm{C}^{13} / \mathrm{C}^{12}$ isotope ratio measurements were made. All organic samples underwent pretreatment with $1 \% \mathrm{NaOH}$ and with $1 \%$ HCI solutions. Carbonate samples were pretreated with $0.1 \% \mathrm{HCl}$ to remove surface contamination resulting from adsorption of atmospheric $\mathrm{CO}_{2}$.

For the first time corrected ages which take account of secular variations of atmospheric $\mathrm{C}^{14}$ level are included in this date list. These ages, denoted "Bristlecone-pine age", give dendrochronologically determined ages of bristlecone-pine wood with the same $\mathrm{C}^{14}$ content as the sample (Stuiver, 1966).

\footnotetext{
* Present address: Dept. of Chemistry, University of California, Los Angeles.
} 


\section{ACKNOWLEDGMENTS}

Operation of the La Jolla Laboratory is financed by grant GA-25952 from the National Science Foundation and respective predecessor grants, to H. E. Suess as principal investigator. Also greatly appreciated is the financial aid obtained from the National Science Foundation (Grant GA-1631) for the construction of the new laboratory. Don Sullivan was responsible for construction and maintenance of the electronic equipment. Mass spectrometric $\delta \mathrm{C}^{13}$ measurements were carried out in the laboratory of H. Craig (1961). T. W. Linick and W. Kosiba helped with editing this paper. Gratitude is expressed to H. L. Smith, K. Bailey, and K. Bloshko for technical assistance.

\section{ARCHAEOLOGIC SAMPLES \\ A. Ancient Central European cultures}

The following 8 samples subm. by Evzen Neustupny, Ceskoslovenska Akad. Ved, whose comments appear.

\section{$\begin{array}{ll}\text { LJ-2032. Linear Pottery culture, middle phase } & 6200 \pm 300 \\ & 4250 \text { B.C. }\end{array}$ Bristlecone-pine age $5230+210$ B.C. $-390$}

Charcoal from Pit 733 of Neolithic village. Excavated 1960 by B. Soudsky and I. Pavlu. Bylany dist. Kutna Hora, Bohemia. Previously determined radiocarbon age: 6200 B.P. Comment (E.N.): age differs less than standard error from expected. LJ-2037 and LJ-2040 should be 100 to $200 \mathrm{yr}$ older (Agrawal, 1968).

\section{LJ-2037. Linear Pottery culture, late phase \\ $6300 \pm 300$} B. Soudsky l. Soudsky and I. Pavlu. Bylany dist. Kutna Hora, Bohemia. A previous determination gave 6000 B.P. (Kohl, 1964, 1966). Comment (E.N.): dates IVth of the 5 phases of Linear Pottery culture. Thus, one. would expect a date at the end of the 7 th millennium B.P. (see LJ-2040). Age agrees well with LJ-2040, from immediately following archaeologic phase.

\section{LJ-2040. Linear Pottery culture, late phase \\ $6300 \pm 300$}

Charcoal from Neolithic Pit 330. Excavated 1957 by E PleslovaStikova, Dnoboh-Hrada, Dist. Mnichovo Hradiste, Bohemia. Previously determined age is 6000 B.P. Comment (E.N.): dates the last (Vth) phase of the Linear Pottery culture. Other dates for this phase, which should have lasted ca. 100 yr: BLN-559:6260, BLN-558:6170, BLN-73:5945, GRN-1581:5920, BLN-176:5932, BLN-557:5565. There are now ca. 50 dates for the Linear Pottery culture (Linear-bandkeramik) unfortunately mostly unassignable to respective phases of its development. They cluster densely between 6450 and 5900 B.P. 


\section{LJ-2042. Late Bronze age, upper layer Bristlecone-pine age

Charcoal from Neolithic Pit 300h. Excavated 1957 by E. PlesovaStikova, Dnoboh-Hrada, dist. Mnichovo Hradiste, Bohemia. Comment (E.N.): Pit. No. 300h had 2 layers; this sample from upper layer belonged to Lausitz culture of Late Bronze age; lower layer belonged to Neolithic period. Other dates for this period: BLN-398, $2860 \pm 120$; ST-201, $2810 \pm 75$; UCLA-1485A, $2860 \pm 60$; UCLA-1485B, $2900 \pm 60$; UCLA$1485 \mathrm{C}, 2885 \pm 60$. When calibrated, dates suggest 11 th century B.C., traditional estimate for this archaeologic period.

\section{LJ-2044. Early Bronze age, middle layers}

\section{Bristlecone-pine age}

$3350 \pm 200$

\section{B.C.}

$1670+400$ B.C.

$$
-200
$$

Charcoal from middle layers of Early Bronze age. Coll. 1957 by E. Neustupny-Madnovce culture. Nitriansky Hradok, dist. Nove Zanky, Slovakia. Assumed historic age (A.H.A.) 1550 в.c. but probably much older. Comment (E.N.): result is somewhat lower than expected as sample is believed contemporaneous with LJ-2047 and LJ-2048. Because sample comes from charred beams of a rampart, a slightly earlier date than the aforementioned measurements (Rodden, 1962) is expected.

\section{LJ-2047. Early Bronze age village \\ Bristlecone-pine age \\ $3600 \pm 200$ \\ 1650 B.C. \\ $2100+80$ в.с.

$$
-400
$$

Charcoal from Pit 3/58 of Early Bronze age village. Excavated 1958 by V. Moucha, Slanska Hora dist. Slany, Bohemia. Late Unetice (Veterov) culture. Assumed historic age is 1550 в.c., but probably older. See LJ2048 for description (Agrawal, 1965).

\section{LJ-2048. Early Bronze age \\ Bristlecone-pine age \\ $3650 \pm 200$ \\ 1700 B.c. \\ 1300 B.C.
$2130+70$ B.C. $-300$}

Charcoal from an Early Bronze age village. Excavated by J. Ondracek. Veterov culture. Budkovice dist., Brno, Moravia. A.H.A. 1550 в.c., but probably much older. Comment (E.N.): should be roughly contemporaneous on archaeologic grounds with LJ-2047. Other dates for this period BLN-248: $3613 \pm 160$, GRN-5037: $3605 \pm 40$, and BLN475: $3845 \pm 80$. These dates for end of Central-European Early Bronze age, when calibrated, suggest that this period ended 400 to $500 \mathrm{yr}$ earlier than formerly believed, based on archaeologic comparisons. They corroborate chronology proposed by Neustupny in 1967 and 1968. The end 
of the Early Bronze age at ca. 1550 to 1450 B.c. has been considered one of best known archaeologic dates, but it is clearly off by many centuries.

\section{LJ-2053. Late Lengyel culture \\ $\mathbf{3 8 5 0}$ в.C. \\ $\mathbf{5 8 0 0} \pm \mathbf{3 0 0}$ \\ Bristlecone-pine age \\ $4760+240$ B.C.$$
-280
$$

Charcoal from Pit 708 of Neolithic village. Excavated 1960 by B. Soudsky and I. Pavlu, Bylany dist. Kutna Hora, Bohemia. A.H.A. 5600 B.P. (Crane, 1968). Comment (E.N.): earlier than expected by $>200 \mathrm{yr}$. No direct comparison is possible with other dates. Pit contained a mixture of earlier Neolithic pottery fragments; sample was possibly contaminated by somewhat older charcoal.

\section{B. Upper Paleolithic}

Ten samples subm. by A. J. Jelinek, Haifa, Israel; coll. from et Tabun, Mt. Carmel, Israel, and were composed of very black soil from obvious hearth or other burned areas. Three such samples were previously dated by Groningen Lab. at ca. 40,000 yr B.P. See Smith (1964) for other dates corresponding to this period. Expected to date the Upper Paleolithic Carmel culture, but appeared in part to be contaminated with modern material.

\section{LJ-2059. $\quad 23,000 \pm 2500$}

t69, 26-VII; $325 \mathrm{~cm}$ deep. Sq. 16, Bed 30. NW corner.

LJ-2061.

$30,500 \pm 2500$

28,550 в.c.

t69, 24-VI; Sq. 2, Bed 15. 30-46 s, 20-42 e, 246 to $255 \mathrm{~cm}$ deep.

LJ-2068.

$31,400 \pm 3500$ deep.

t69, 12-VII, Sq. 3, Bed 15 (top), 0-25 s, 65-100 e, 235 to $240 \mathrm{~cm}$

LJ-2070.

$>\mathbf{3 0 , 0 0 0}$

$>\mathbf{2 8 , 0 5 0}$ в.с.

t69, 18-VI; Sq. 3, Bed 7 (basal), 0-25 s, $50-100$ e, 195 to $205 \mathrm{~cm}$ deep (Jelinek, 1960).

\section{LJ-2075.}

$31,500 \pm 3200$

\section{LJ-2078.} deep.

t69, 13-VII; Sw. 3, Bed 18 (basal), 30-50 s, 80-100 e, 263 to $265 \mathrm{~cm}$

$28,200 \pm 3000$

26,250 в.c. 


\section{LJ-2082.}

t69, Sq. 5, Bed 18, 15-40 e, 60-85 s, 220 to $235 \mathrm{~cm}$ deep.

$38,800 \pm 2400$

LJ-2084.

36,850 в.с.

t69, 21-VII; $520 \mathrm{~cm}$ deep, 0-20 s, 50-80 e, Sq. 22, Bed 42.

$24,900 \pm 3000$

LJ-2087.

22,950 в.c.

t69, 3-VII; 66-100 e, 0-100 s, Sq. 5, Bed 21 (W 1/3 of sq.) average depth $=228 \mathrm{~cm}$.

$28,500 \pm 2400$

\section{LJ-2090.}

26,550 в.c.

t69, 21-VII; ca. 50-80 e, 0-20 s, lower hearth, Sq. 22, Bed $42.520 \mathrm{~cm}$ deep. Comment: Samples LJ-2059, 2061, 2078, 2087 appear too young due to contamination with rootlets and other modern material.

\section{Anza series, Macedonia, Yugoslavia}

Anza, a Neolithic habitation site, is adjacent to the modern village of Anzabegovo, midway between the towns of Stip and Titov Veles in the Ovce Polje basin, E. Macedonia, Yugoslavia. The settlement lies on a small tributary of the R. Bregalnica in the Aegean drainage basin of the middle Vardar R. The greatest stratified depth found at Anza was ca. $4 \mathrm{~m}$, comprising Neolithic deposits which were subdivided into 3 phases; Anza I (Early); Anza II (Middle); and Anza III (Late). In current archaeologic terminology Anza I is analogous to earliest Starcevo/ Proto-Sesklo; Anza II to middle-late Starcevo; and Anza III to Early Vinca. No later prehistoric deposits were found at Anza and no traces of later Neolithic-Chalcolithic occupation have been found anywhere in E. Macedonia. The Anza III deposit was immediately overlain, in the center of the site, by remains of Roman habitation. Sponsored by the Smithsonian Inst. Foreign Currency Program, excavation was conducted during the summers of 1969 and 1970 by a joint team of Yugoslav and American archaeologists. Samples coll. and subm. by Marija Gimbutas and Geoffrey Sayer.

\section{LJ-2156.}

$6630 \pm 300$

Charcoal from Sq. VII, Unit 156; a well-preserved fire pit of midAnza II phase. $354 \mathrm{~cm}$ below site datum point.

\section{LJ-2157.}

$7030 \pm 330$

\section{0 в.c.}

Charcoal from Sq. VII, Unit 204, early Anza II phase. 380 to 383 $\mathrm{cm}$ below site datum point. 
LJ-2181.

$7340 \pm 250$

5390 в.C.

Charcoal from Sq. V, Unit 111, Anza I phase. $395 \mathrm{~cm}$ below site datum point.

LJ-2342.

$7120 \pm 200$

5170 B.C.

Charcoal sample from Sq. VII, Unit 251. Early Anza (I) phase.

D. California Indians

\section{LJ-1982. La Jollan Sweat House}

$3650 \pm 180$

1700 B.c.

Bristlecone-pine age $2130+40$ B.c.

$$
-300
$$

Charcoal, coll. 1945, subm. by E. L. Davis, San Diego Mus. of Man. W-154, SDMM-Soledad Heights. Level $1.7 \mathrm{~m}$ below surface. Alt. 167.8 $\mathrm{m}$, Soledad Heights, Quat sheet-La Jolla $\left(32^{\circ} 40^{\prime} 30^{\prime \prime} \mathrm{N}\right.$ Lat, $117^{\circ} 15^{\prime}$ 30 " W Long). Comment: should date lower level of a coastal, Milling Archaic horizon (Warren, 1964).

\section{Bristlecone-pine age $1610+70$ в.c. $-140$}

Charcoal subm. 1969 by David Kinder, San Diego State College. SDMM W-370. $58 \mathrm{~cm}$ below ground level from Pit $+5+10,15 \mathrm{~min}$ series. Alt. $793 \mathrm{~m}\left(32^{\circ} 38^{\prime} \mathrm{N}\right.$ Lat, $115^{\circ} 45^{\prime} \mathrm{W}$ Long). Comment: will help determine introduction of pottery into San Diego Co. (Warren, 1961).

\section{LJ-1990. Coastal Archaic shell midden}

$43,000 \pm 2200$

Charcoal subm. 1969 by Dirk Chodfelter, Del Mar, Calif. SDMM $\mathrm{W}-20$. From Site A area of site W-20, $92 \mathrm{~cm}$ below present soil level and at base of a 20 to $25 \mathrm{~cm}$ shell midden lens from Trench 1, Pit 2 of Site A. $\left(32^{\circ} 56^{\prime} \mathrm{N}\right.$ Lat, $117^{\circ} 14^{\prime} 05^{\prime \prime} \mathrm{W}$ Long). Comment: temporal placement of another coastal shell midden and to complement and be used for comparison with other carbon dates from $\mathrm{W}$-20 material.

\section{LJ-1992. Jamul Quadrangle}

A.D. 1550

$$
600 \pm 100
$$

Same as LJ-1984. Charcoal coll. 1969, from $32 \mathrm{~cm}$ below present floor of rock shelter from Pit 0, r10.

\section{LJ-1994. La Jollan Sweat House}

A.D. 1831

$$
340 \pm 50
$$

See LJ-1982. Site SDMM W-167. Deepest level of sweat house. Alt. 76.3 m Oceanside Quad. $38 \mathrm{~cm}\left(33^{\circ} \mathrm{I}^{\prime} 45^{\prime \prime} \mathrm{N}\right.$ Lat, $117^{\circ} 15^{\prime} 30^{\prime \prime} \mathrm{W}$ Long). Comment: dates lowest level of a La Jolla II (Late Milling Archaic) site, intrusive in San Dieguito level. 
General Comment: last 2 samples subm. by J. D. Hedrick, San Diego State College in his study concerning the migration of Melanesians in Polynesia. Distribution and lack of similarity to other Melanesian pottery suggests a discrete migration from SE Asia through the Pacific to W Polynesia.

$1170 \pm 200$

\section{LJ-1906. Avnitari Village, Melanesian culture A.D. 780}

Bristlecone-pine age A.D. 830 E Long). Site designation NHMa-7, Avnitari Village, Malo Is., New Hebrides. Alt. $12.8 \mathrm{~m}$, on elevated coral reef. Located $91.5 \mathrm{~m}$ above original occupation level with clate of 2020 B.P. (UCLA-1412).

\section{LJ-1907. Avnitari Village}

Charcoal and ash from fire hearth, coll. 1968. AVN 0719, (15 $42^{\prime} \mathrm{S}$ Lat, $167^{\circ} 07^{\prime} \mathrm{E}$ Long). Alt. $12.8 \mathrm{~m}$ on elevated coral reef. $56 \mathrm{~cm}$ layer, Malo-7, Pit 1, Hearth 3. Lapita pottery preliminary date 2020 B.P. at $1.2 \mathrm{~m}$ level.

\section{LAKE IECONTE BASIN STUDY}

Thirteen samples subm. by G. M. Stanley, Fresno State College as part of the study of the shoreline history of Lake LeConte. (See review of part of Lake LeConte (Hubbs, 1965).

\section{LJ-GAP 0093. Lake LeConte}

$30,600 \pm 1500$

Box Canyon Wash, .96 to $1.12 \mathrm{~km} \mathrm{NE}$ of Hwy 195 bridge over Coachella Canal, NE 1/4 Sec. 12, T7S, R9E, and Sec. 7 adjoining on E, Riverside Co., California (33 $34.72^{\prime} \mathrm{N}$ Lat, $115^{\circ} 59.575^{\prime} \mathrm{W}$ Long). Coll. 1964. Inner and outer layers of tufa. Combined B-2b, B-2c, B-2d.

\section{LJ-1625. Lake LeConte}

$>45,000$

43,050 B.c.

Box Canyon Wash, .96 to $1.12 \mathrm{~km}$ NE of Hwy 195 bridge over Coachella Canal, NE 1/4 of Sec. 12, T7S, R9E, and Sec. 7 adjoining on E, Riverside Co., Calif. (33 $34.72^{\prime} \mathrm{N}$ Lat, $115^{\circ} 59.575^{\prime} \mathrm{W}$ Long). Coll. 1964. B-16.

\section{LJ-1627. Lake LeConte}

$$
29,000 \pm 1500
$$

$.6 \mathrm{~km}$ WSW of Travertine Rock, from alt. 14.3 to $18.3 \mathrm{~m}$, from singular shoreline antedating last stages of Lake LeConte. Imperial Co., California. Coll. 1964. (39 $24.96^{\prime} \mathrm{N}$ Lat, $116^{\circ} 04.37^{\prime} \mathrm{W}$ Long). Tufa, broken from marble ledge; marble grains were scraped away. WTR-17. 


\section{LJ-1628. Lake LeConte}

$36,000 \pm 2000$

Box Canyon Wash, .96 to $1.12 \mathrm{~km} \mathrm{NE}$ of Hwy. 195 bridge over Coachella Canal, NE 1/4 Sec. 12, T7S, R9E, and Sec. 7 adjoining on E, Riverside Co., Calif. (33 $34.72^{\prime} \mathrm{N}$ Lat, $115^{\circ}$ 59.575' W Long). Coll. 1964. Larger pieces containing inner and outer tufa layers and innermost, gypsum. B-2e.

\section{LJ-1629. Lake LeConte}

$29,200 \pm 1500$

$.6 \mathrm{~km}$ WSW of Travertine Rock, from alt. 14.3 to $18.3 \mathrm{~m}$, from singular shoreline antedating last stages of Lake LeConte. Imperial Co.,

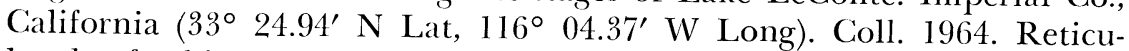
lated tufa chipped from marble slabs broken from bedrock. Marble and surface lichen were scraped off. WTR-13.

\section{LJ-1630. Lake LeConte}

$31,200 \pm 1600$

Box Canyon Wash, .96 to $1.12 \mathrm{~km}$ NE of Hwy. 195 bridge over Coachella Canal, NE 1/4 Sec. 12, T7S, R9E, and Sec. 7 adjoining on E, Riverside Co., California (33 $34.72^{\prime}$ N Lat, $115^{\circ} 59.575^{\prime}$ W Long). Coll. 1964. Firm, reticulated tufa, chipped from schist. B-1.

\section{LJ-1631. Lake LeConte}

$33,400 \pm 1700$

Box Canyon Wash, .96 to $1.12 \mathrm{~km} \mathrm{NE}$ of Hwy. 195 bridge over Coachella Canal, NE 1/4 Sec. 12, T7S, R9E, and Sec. 7 adjoining on E, Riverside Co., California (33 $34.76^{\prime} \mathrm{N}$ Lat, $115^{\circ} 59.50^{\prime} \mathrm{W}$ Long). Coll. 1964. Tufa chipped from fine-grained granite which persistently broke off in small slivers attached to inner side of tufa chips. Tufa surface is reticulated. F-3.

\section{LJ-1632. Lake LeConte}

$21,800 \pm 1000$

$.6 \mathrm{~km}$ of Travertine Rock, from alt. 14.3 to $18.3 \mathrm{~m}$, from singular shoreline antedating last stages of Lake LeConte. Imperial Co., California ( $33^{\circ} 24.96^{\prime} \mathrm{N}$ Lat, $116^{\circ} 04.37^{\prime} \mathrm{W}$ Long). Coll. 1964. Tufa, broken from marble ledge, scraped and scrubbed to remove lichen. WTR-18a.

\section{LJ-1633. Lake LeConte}

$>45,000$ B.c.

Box Canyon Wash, .96 to $1.12 \mathrm{~km} \mathrm{NE}$ of Hwy. 195 bridge over Coachella Canal, NE 1/4 Sec. 12, T7S, R9E, and Sec. 7 adjoining on E, Riverside Co., California. Coll. 1964. Outer, sandy tufa; crumbly. Separated from layer of firm inner tufa. B-2.

\section{LJ-1634. Lake LeConte}

$24,000 \pm 1200$

$.6 \mathrm{~km} \mathrm{WSW}$ of Travertine Rock, from alt. 14.3 to $18.3 \mathrm{~m}$, from singular shoreline antedating the last stages of Lake LeConte, Imperial Co., California. Coll. 1964. (39² $24.96^{\prime} \mathrm{N}$ Lat, $116^{\circ} 04.37^{\prime} \mathrm{W}$ Long). 
Tufa, chipped from $38 \mathrm{~cm}$ chunk of marble broken from ledge, scrubbed to remove surface lichen. WTR-12.

\section{LJ-1635. Lake LeConte}

$36,900 \pm 1900$

34,950 B.C.

Box Canyon Wash, .96 to $1.12 \mathrm{~km} \mathrm{NE}$ of Hwy. 195 bridge over Coachella Canal, in NE 1/4 Sec. 12, T7S, R9E, and Sec. 7 adjoining on E, Riverside Co., California. Coll. 1964. (33 $34.77^{\prime} \mathrm{N}$ Lat, $115^{\circ} 59.465^{\prime}$ W Long). Tufa, chipped from $17.8 \mathrm{~cm}$ angular gneiss. Tufa coatings are pinkish and have a knobby, very irregular surface; resemble tufa of recent age as at water surface of Pyramid Lake, Nevada. P-15.

$26,200 \pm 1500$

\section{LJ-1636. Lake LeConte}

\section{4,250 в.C.}

Box Canyon Wash, .96 to $1.12 \mathrm{~km} \mathrm{NE}$ of Hwy. 195 bridge over Coachella Canal, in NE 1/4 Sec. 12, T7S, R9E, and Sec. 7 adjoining on E, Riverside Co., California ( $33^{\circ} 34.72^{\prime} \mathrm{N}$ Lat, $115^{\circ} 59.575^{\prime} \mathrm{W}$ Long). Coll. 1964. Tufa chips, chipped from pinkish blocky $12.7 \mathrm{~cm}$ granite. A-6.

\section{LJ-1637. Lake LeConte}

$25,600 \pm 1300$

Box Canyon Wash, .96 to $1.12 \mathrm{~km} \mathrm{NE}$ of Hwy. 195 bridge over Coachella Canal, in NE 1/4 Sec. 12, T7S, R9E, and Sec. 7 adjoining on E, Riverside Co., California (33 $34.74^{\prime} \mathrm{N}$ Lat, $115^{\circ} 59.54^{\prime} \mathrm{W}$ Long). Coll. 1964. Tufa, chipped from $12.7 \mathrm{~cm}$ rounded granite cobble, abundantly covered with reticulated tufa. D-7. This sample is from the same tufa line as LJ-450, dated as $>35,000$ yr B.P.

\section{GEOLOGIC AND OCEANOGRAPHIC SAMPLES}

\section{A. Sedimentation}

Ages given are only apparent ages. Since age difference gives a time scale for sedimentation rate pertinent to sedimentologists, we refer to apparent age instead of $\delta \mathrm{C}^{14}$ or $\Delta \mathrm{C}^{14}$, which would be misleading to sedimentologists.

Geologic subm. by E. L. Winterer. MO5 $(70$ to $104 \mathrm{~cm})$. Coral Sea abyssal plain, $2453 \mathrm{Fms}$. (13 $13^{\circ} 45^{\prime} \mathrm{S}$ Lat, $150^{\circ} 02^{\prime} \mathrm{E}$ Long). Woody material in turbidite layer. Comment: dates a turbidite layer in same core as M5 (26 to $33 \mathrm{~cm}, \mathrm{LJ}-1904)$, to $(79$ to $104 \mathrm{~cm}, \mathrm{LJ}-1905)$, to give an idea of time interval between turbidites, and rate of deposition.

\section{LJ-1904. Turbidite layer}

$26,000 \pm 1500$

(26 to $33 \mathrm{~cm}$ from top of core).

\section{LJ-1905. Turbidite layer}

$$
28,500 \pm 1500
$$

(79 to $33 \mathrm{~cm}$ from top of core).

General Comment: the following 5 samples subm. by Roger Anderson; coll. 1969 during the cruise Atlantis II-54-leg 2. Samples were $80 \%$ to $90 \% \mathrm{CaCO}_{3}$ pelagic sediment. A detailed topographic and heatflow survey indicated possible recent sediment slump in the area of Stas. 31 
and 35. If slump could be confirmed by dating, a significant environmental distortion to observed heat flow in the area would also be confirmed (Arrhenius, 1952).

\section{LJ-2322.}

Sta. 31,0 to $19 \mathrm{~cm}$ deep in core. Depth: $3425 \mathrm{~m}$. ( $6^{\circ} 24.2^{\prime} \mathrm{S}$ Lat, $105^{\circ} 47.4^{\prime} \mathrm{W}$ Long).

\section{LJ-2324.}

Sta. 35,890 to $905 \mathrm{~cm}$ deep in core. Depth: $3360 \mathrm{~m}$. $\left(6^{\circ} 18.5^{\prime} \mathrm{S}\right.$ Lat, $105^{\circ} 40.8^{\prime}$ W Long).

\section{LJ-2186.}

$$
\mathbf{5 6 0 0} \pm \mathbf{2 0 0}
$$

Sta. 35,0 to $20 \mathrm{~cm}$ deep in Core. Depth: $3360 \mathrm{~m}$. $\left(6^{\circ} 18.5^{\prime} \mathrm{S}\right.$ Lat, $105^{\circ} 40.8^{\prime}$ W Long).

\section{LJ-2189.}

$34,600 \pm 3000$

Sta. 31, 373 to $392 \mathrm{~cm}$ deep in core. Depth: $3425 \mathrm{~m}$. (6 $6^{\circ} 24.2^{\prime} \mathrm{S}$ Lat, $105^{\circ} 47.4^{\prime}$ W Long).

\section{LJ-2190.}

Sta. 35, 442 to $457 \mathrm{~cm}$ deep in core. Depth: $3360 \mathrm{~m}$. $\left(6^{\circ} 18.5^{\prime} \mathrm{S}\right.$ Lat, $105^{\circ} 40.8^{\prime}$ W Long).

\section{LJ-2191.}

Sta. 31, 737 to $753 \mathrm{~cm}$ deep in core. Depth: $3425 \mathrm{~m}$. (6 $6^{\circ} 24.2^{\prime} \mathrm{S}$ Lat, $105^{\circ} 47.4^{\prime} \mathrm{W}$ Long).

General Comment: the following 3 samples subm. by J. L. Bada. Results are being used to check age with that determined by excess $T h^{230}$, and to check validity of alloisoleucine/isoleucine ratios as a dating method. Mixing between upper core layers is also under study.

\section{LJ-2168. Deep-sea core $\quad 13,000 \pm 400$}

CH 96-G12, 25 to $35 \mathrm{~cm}$ level. $\left(30^{\circ} 15.7^{\prime} \mathrm{N}\right.$ Lat, $43^{\circ} 19.8^{\prime} \mathrm{W}$ Long) (Nayudu, 1964).

\section{LJ-2195. Deep-sea core}

CH 96-G12, 45 to $55 \mathrm{~cm}$ level. ( $30^{\circ} 15.7^{\prime} \mathrm{N}$ Lat, $43^{\circ} 18.9^{\prime} \mathrm{W}$ Long). Coll. 1969.

\section{LJ-2323. Lake core}

1650 to $1660 \mathrm{~cm}$ level. Coll. 1969.

$$
18,600 \pm 1025
$$

\section{B. Feeding habits of pelagic organisms}

9 samples subm. by P. M. Williams in study of feeding habits and food sources of pelagic organisms, particularly referring to their placement in the marine biological food chain. These samples were coll. alive; ages assigned are only apparent ages reflecting their food. Refer to Berger (1966) and Rubin (1963) for marine shell measurements. 
LJ-2111. Brittle Star

$$
\begin{array}{r}
2180 \pm 100 \\
\Delta \mathbf{C}^{14}=-\mathbf{2 2 8 . 2} \% \\
\delta C^{13}=-6.5 \%
\end{array}
$$

$\mathrm{CaCO}_{3}$ fraction dated from Serial M III. Coll. 1970 at depth 3900 m (31 $47^{\prime}$ N Lat, $120^{\circ} 19^{\prime}$ W Long). (McGowan, 1970).

\section{LJ-2113. Starfish}

$$
\begin{array}{r}
\mathbf{2 2 7 0} \pm \mathbf{1 0 0} \\
\Delta \mathbf{C}^{14}=-\mathbf{2 3 6 . 6} \% \\
\delta C^{13}=-5.71 \%
\end{array}
$$

$\mathrm{CaCO}_{3}$ fraction dated from Serial M II. Coll. 1970 at depth 3900 m. (31 $47^{\circ} \mathrm{N}$ Lat, $120^{\circ} 19^{\prime} \mathrm{W}$ Long).

\section{LJ-2115. Starfish}

$$
\begin{array}{r}
\mathbf{8 2 0} \pm \mathbf{2 0} \\
\Delta \mathbf{C}^{14}=-\mathbf{8 6 . 2} \% \\
\delta C^{13}=-20.5 \%
\end{array}
$$

Organic matter from Serial M II (LJ-2113).

\section{LJ-2116. Shrimp (Systellaspis braueri)}

$$
340 \pm 20
$$

$$
\begin{aligned}
\Delta \mathbf{C}^{14} & =-\mathbf{3 . 6} \% \\
\delta C^{13} & =-21.8 \%
\end{aligned}
$$
$1600 \mathrm{~m}$.

Serial M I (31 $01^{\prime} \mathrm{N}$ Lat, $119^{\circ} 30^{\prime} \mathrm{W}$ Long). Coll. 1970 at depth

LJ-2118. Fish

$$
\begin{array}{r}
\mathbf{6 8 5} \pm \mathbf{5 0} \\
\Delta \mathbf{C}^{14}=\mathbf{8 9 . 2} \% \\
\delta C^{13}=-22.8 \%
\end{array}
$$

Serial CL IV, Climax II. Coll. 1970 at depth $1500 \mathrm{~m}$. $\left(28^{\circ} 31^{\prime} \mathrm{N}\right.$ Lat, $155^{\circ} 29^{\prime} \mathrm{W}$ Long).

\section{LJ-2127. Fish}

$$
\begin{array}{r}
\mathbf{3 5 0} \pm \mathbf{2 0} \\
\Delta \mathbf{C}^{14}=\mathbf{0 . 7} \% \\
\delta C^{13}=-21.8 \%
\end{array}
$$

Climax II, CL II. Coll. 1970 at depth $1500 \mathrm{~m}$. (28 31' N Lat, $155^{\circ} 29^{\prime}$ W Long).

\section{LJ-2128. Fish}

$$
\begin{array}{r}
-135 \pm 10 \\
\Delta \mathbf{C}^{14}=\mathbf{1 7 . 7} \% \\
\delta C^{13}=-19.9 \%
\end{array}
$$

Climax II. CL I. Coll. 1970 at depth 1500 m. (28 $31^{\prime}$ N Lat, $155^{\circ}$ $29^{\prime}$ W Long).

\section{LJ-2130. Fish}

Climax II, CL III. Coll. 1970 at depth 1500 m. (28 31' N Lat, $155^{\circ}$ 29' W Long).

\section{REFERENCES}

Agrawal, D. P. and Kusumgar, Sheela, 1968, Tata Institute radiocarbon date list V: Radiocarbon, v. 10, p. 131-143.

Agrawal, D. P., Kusumgar, S., and Lal, D., 1965, Tata Institute radiocarbon date list III: Radiocarbon, v. 7, p. 291-295.

Arrhenius, G., 1952, Sediment cores from the East Pacific: Reports of the Swedish

Deep-Sea Expedition 1947-1948, v. 5, fasc. 1, p. 1-227. 
Berger, R., Taylor, R. E., and Libby, W. F., 1966, Radiocarbon content of marine shells from the California and Mexican West Coast: Science, v. 153, no. 3788, p. $864-866$, fig. 1 .

Craig, Harmon, 1961, Mass-spectrometer analyses of radiocarbon standards: Radiocarbon, v. 3, p. 1-3.

Crane, H. R. and Griffin, J. B., 1968, University of Michigan radiocarbon dates XII: Radiocarbon, v. 10, p. 61-114.

Hubbs, C. L., Bien, G. S., and Suess, H. E., 1965, La Jolla natural radiocarbon measurements IV: Radiocarbon, v. 7, p. 66-117.

Hubbs, C. L. and Roden, G. I., 1964, Oceanography and marine life along the Pacific coast of middle America, in: Handbook of Middle American Indians: Austin, Univ. of Texas Press, v. 1, p. 143-186.

Jelinek, A. J., 1960, An archaeological survey of the middle Pecos River and the adjacent Llano Estacado: Univ. of Michigan, Univ. Microfilms, Ph.D. dissertation. Kohl, G. and Quitta, H., 1964, Berlin radiocarbon measurements I: Radiocarbon,
v. 6, p. 308-317.

1966, Berlin radiocarbon measurements II: Radiocarbon, v. 8, p. 27-45.

Mcciowan, J. A., Stuiver, M., and Williams, P. M., 1970, Bomb carbon-14 in deep sea organisms: Nature, v. 227, no. 5256, p. 375-376.

Nayudu, Y. R., 1964, Carbonate deposits and paleoclimatic implications in the northeast Pacific Ocean: Science, v. 146, no. 3643, p. 515-517.

Rodden, R. J., 1962, Excavations at the early neolithic site of Nea Nikomedeia, Greek Macedonia (1961 season): Prehist. Soc. Proc., v. 28, p. 267-288.

Rubin, M. and Taylor, D. W., 1963, Radiocarbon activity of shells from living clams and snails: Science, v. 141, no. 3581, p. 637.

Sixth International Conf. $\mathrm{C}^{14}$ and $\mathrm{H}^{3}$ Dating, June 7-11, Pullman, Washington, 1965, U.S. Atomic Energy Commission.

Smith, P. E. L., 1964, Radiocarbon dating of a Late Paleolithic culture from Egypt: Science, v. 145 , p. 8111 .

Stuiver, Minze and Suess, H. E., 1966, On the relationship between radiocarbon dates and true sample ages: Radiocarbon, v. 8, p. 534-540.

Suess, H. E., 1970a, The three causes of the secular carbon-14 fluctuations, their amplitudes and time constants, in: Proc. of the XII Nobel symposium on radiocarbon variations and absolute chronology, Uppsala, 1969, Almquist and WiksellGebers forlag AB, Stock holm, I. Olsson (ed.), p. 595-605.

$1970 \mathrm{~b}$, Bristlecone pine calibration of the radiocarbon time scale 5300 B.c. to the present, in: Proc. of the XII Nobel symposium on radiocarbon variations and absolute chronology, Uppsala, 1969. Almquist and Wiksell-Gebers Forlag AB, Stockholm, I. Olsson (ed.), p. 303-313.

Vogel, J. C. and Waterbolk, H. T., 1967, Groningen radiocarbon dates VII: Radiocarbon, v. 9, p. 107-155.

Warren, C. N., 1964, Cultural change and continuity on the San Diego coast: Univ. of California, Los Angeles, Ph.D. dissertation.

Warren, C. N., True, D. L., and Eudey, A. A., 1961, Early gathering complexes of western San Diego County: Results and interpretations of an archeological survey: Univ. of California, Los Angeles, Archaeol. Survey Ann. Rept. 1960-1961, p. 1-106, graphs 1-3, figs. 1-11. 